\title{
THE
}

6-2012

\section{In Vitro Coagulation Effects of Ophthalmic Doses of Bevacizumab}

Kerry L. LaPlante

University of Rhode Island, kerrylaplante@uri.edu

$\mathrm{Li}$

Paul B. Greenberg

Victoria Tseng

Suzanne B. Woodmansee

See next page for additional authors

Follow this and additional works at: https://digitalcommons.uri.edu/php_facpubs

Terms of Use

All rights reserved under copyright.

\section{Citation/Publisher Attribution}

Li, E., Greenberg,P. B., Tseng, V., Woodmansee, S. B., Caffrey, A. R., Wu, W.-C., Friedmann, P. D., \& LaPlante, K. L. (2012). In Vitro Coagulation Effects of Ophthalmic Doses of Bevacizumab, Journal of Ocular Pharmacology and Therapeutics, 28(3), 219-221. doi: 10.1089/jop.2011.0148

Available at: http://dx.doi.org/10.1089/jop.2011.0148

This Article is brought to you for free and open access by the Pharmacy Practice at DigitalCommons@URI. It has been accepted for inclusion in Pharmacy Practice Faculty Publications by an authorized administrator of DigitalCommons@URI. For more information, please contact digitalcommons-group@uri.edu. 


\section{Authors}

Kerry L. LaPlante, Li, Paul B. Greenberg, Victoria Tseng, Suzanne B. Woodmansee, Aisling R. Caffrey, WenChih Wu, and Peter D. Friedmann 


\title{
In Vitro Coagulation Effects of Ophthalmic Doses of Bevacizumab
}

\author{
Emily Li, ${ }^{1}$ Paul B. Greenberg, ${ }^{2-4}$ Victoria Tseng, ${ }^{2-4}$ Suzanne B. Woodmansee, ${ }^{3}$ \\ Aisling R. Caffrey,, Wen-Chih Wu, ${ }^{3,4}$ Peter D. Friedmann,, ${ }^{3,4}$ and Kerry L. LaPlante ${ }^{3-6}$
}

\begin{abstract}
Purpose: In vitro coagulation effects of bevacizumab, a drug with potential risks for severe hemorrhagic and arterial thromboembolic events (ATEs), are unknown. The aim of this study was to evaluate the effects of bevacizumab, including the common ophthalmic dose of $1.25 \mathrm{mg}$, on the coagulation cascade.

Methods: Bevacizumab doses of 0.25, 0.5, 1.0, 1.25, 2.0, 2.5, and $4.0 \mathrm{mg}$ were incubated at $37^{\circ} \mathrm{C}$ in the presence of pooled normal plasma (PNP) to determine its biological activity via activated partial thromboplastin time (aPTT) and prothrombin time (PT) at $30 \mathrm{~min}, 1 \mathrm{~h}$, and $2 \mathrm{~h}$. The control consisted of $40 \%$ normal saline and $60 \%$ PNP. All evaluations were conducted in triplet. Coagulation at each time point was compared with the control group by analysis of variance with Tukey's post hoc test. A $P$ value of $\leq 0.05$ was considered significant.

Results: Mean bevacizumab aPTT ranged from 38.4 to $43.9 \mathrm{~s}, 37.4$ to $43.1 \mathrm{~s}$, and 39.0 to $43.2 \mathrm{~s}$ at $30 \mathrm{~min}, 1 \mathrm{~h}$, and $2 \mathrm{~h}$, respectively. Mean bevacizumab PT ranged from 15.7 to $16.8 \mathrm{~s}$ at $30 \mathrm{~min}, 14.6$ to $16.2 \mathrm{~s}$ at $1 \mathrm{~h}$, and 14.0 to $15.8 \mathrm{~s}$ at $2 \mathrm{~h}$. For the control, aPTT was similar over time (40.1, 40.0, and $40.5 \mathrm{~s}$ ), while PT decreased from 16.5 at $30 \mathrm{~min}$ to $15.4 \mathrm{~s}$ at $2 \mathrm{~h}$. Bevacizumab decreased PT significantly at $2 \mathrm{~h}$, compared with the PNP control, for the following doses: $0.25 \mathrm{mg}$ [difference between means $1.04 \mathrm{~s}, 95 \%$ confidence interval (CI) $0.12-1.96$ ], $1.25 \mathrm{mg}$ (1.16 s, 95\% CI 0.16-2.15), $2.5 \mathrm{mg}(0.94 \mathrm{~s}, 95 \%$ CI $0.02-1.86)$, and $4 \mathrm{mg}$ (1.41 s, 95\% CI 0.41-2.40). Significant differences were not observed in PT at $30 \mathrm{~min}$ and $1 \mathrm{~h}$ as compared with controls. For all doses of bevacizumab, aPTT did not vary from controls at the 3 measured times.

Conclusions: A common ophthalmic dose of bevacizumab $1.25 \mathrm{mg}$ significantly increased in vitro coagulation. Further examination of the impact of ophthalmic bevacizumab on coagulation is warranted to provide insight into any putative link between ophthalmic bevacizumab and the risk for severe ATEs.
\end{abstract}

\section{Introduction}

B EVACIZUMAB is a humanized monoclonal antibody to anti-vascular endothelial growth factor (VEGF) and is approved by the Food and Drug Administration to treat a variety of neoplastic diseases. ${ }^{1}$ When given intravenously (5 mg/kg) for chemotherapy, bevacizumab induces systemic effects, which carries a risk for both hemorrhagic and arterial thromboembolic events (ATEs). ${ }^{2,3}$ Hemorrhage risk includes minor bleeding, most commonly Grade 1 epistaxis, and severe hemorrhage, including hemoptysis and gastrointestinal bleeding. ${ }^{4}$ Major ATEs associated with bevacizumab chemotherapy include cerebral infarction, transient ischemic attacks, myocardial infarction, and angina. ${ }^{4}$

Bevacizumab is also used off-label as an intraocular injection $(1.25 \mathrm{mg} / 0.05 \mathrm{~mL})$ to treat a variety of ophthalmic diseases, such as age-related macular degeneration, retinal vein occlusion, and diabetic retinopathy. ${ }^{1}$ It is unknown, however, whether ophthalmic doses of bevacizumab increase the risk of severe hemorrhagic events or ATEs, as well-controlled clinical trial research has yet to be conducted. $^{4,5}$ Recent research suggests that adverse events associated with ophthalmic bevacizumab include ATEs and

Presented as a poster at the Association for Ocular Pharmacology and Therapeutics 10th Scientific Meeting in Fort Worth, Texas, on February 18, 2011.

${ }^{1}$ Program in Liberal Medical Education, Brown University, Providence, Rhode Island.

${ }^{2}$ Ophthalmology Service and ${ }^{3}$ Research Service, Veterans Affairs Medical Center, Providence, Rhode Island.

${ }^{4}$ Warren Alpert Medical School of Brown University, Providence, Rhode Island.

${ }^{5}$ College of Pharmacy, University of Rhode Island, Kingston, Rhode Island.

${ }^{6}$ Pharmacy Service, Veterans Affairs Medical Center, Providence, Rhode Island. 
other serious adverse reactions. ${ }^{6,7}$ The present study investigated the impact of ophthalmic doses of bevacizumab on the coagulation cascade to provide further insight into its potential systemic effects.

\section{Methods}

Commercially available pharmacy stock of bevacizumab (Genentech, South San Francisco, CA; lot \#761158) was reconstituted with sterile water for injection according to the manufacturer's instructions. Bevacizumab doses of $0.25,0.5$, $1.0,1.25,2.0,2.5$, and $4.0 \mathrm{mg}$ were incubated at $37^{\circ} \mathrm{C}$ in the presence of pooled normal plasma (PNP) to determine its biological activity via activated partial thromboplastin time (aPTT) and prothrombin time (PT) at $30 \mathrm{~min}, 1 \mathrm{~h}$, and $2 \mathrm{~h}$. The control consisted of $40 \%$ normal saline and $60 \%$ PNP. To obtain a dilution with $60 \%$ PNP, ophthalmic doses were achieved in pharmacological testing dose equivalents per milliliter. All evaluations were conducted in triplet.

Mean coagulation was calculated for each dose, as was the difference between mean bevacizumab coagulation and mean control coagulation. Within-dose changes between time points were assessed using the paired t-test. Bevacizumab coagulation at each time point was compared with the control group by analysis of variance with Tukey's post hoc test, and verified with Bonferroni methods. A $P$ value of $\leq 0.05$ was considered significant. All statistical analyses were performed using SAS (SAS Institute, Inc., Cary, NC; Version 9.2).

\section{Results}

Mean bevacizumab aPTT ranged from 38.4 to $43.9 \mathrm{~s}, 37.4$ to $43.1 \mathrm{~s}$, and 39.0 to $43.2 \mathrm{~s}$ at $30 \mathrm{~min}, 1 \mathrm{~h}$, and $2 \mathrm{~h}$, respectively, as shown in Table 1. Mean bevacizumab PT ranged from 15.7 to $16.8 \mathrm{~s}$ at $30 \mathrm{~min}, 14.6$ to $16.2 \mathrm{~s}$ at $1 \mathrm{~h}$, and 14.0 to $15.8 \mathrm{~s}$ at $2 \mathrm{~h}$. For the control, aPTT was similar over time (40.1, 40.0, and $40.5 \mathrm{~s})$, while PT decreased from 16.5 to $15.4 \mathrm{~s}$ $(P=0.004)$. Within bevacizumab doses, aPTT measurements were similar over time, except for $4.0 \mathrm{mg}$, which decreased significantly $(P=0.006)$. Alternatively, PT decreased significantly over time for all bevacizumab doses.

Compared with the PNP control, bevacizumab decreased PT significantly at $2 \mathrm{~h}$ for the following doses: $0.25 \mathrm{mg}$ [dif- ference between means $1.04 \mathrm{~s}, 95 \%$ confidence interval (CI) $0.12-1.96$ ], $1.25 \mathrm{mg}(1.16 \mathrm{~s}, 95 \%$ CI $0.16-2.15), 2.5 \mathrm{mg}$ (0.94 s, 95\% CI 0.02-1.86), and $4 \mathrm{mg}(1.41 \mathrm{~s}, 95 \%$ CI $0.41-2.40)$. No significant differences were observed in PT at $30 \mathrm{~min}$ and $1 \mathrm{~h}$ as compared with controls. For all doses of bevacizumab, aPTT did not vary from controls at the 3 measured time points.

\section{Discussion}

The human coagulation cascade is a series of amplification and activation processes that occur in sequence to generate fibrin monomers, which aggregate spontaneously to form insoluble clots that trap platelets, red blood cells, and other particles to form a thrombus. ${ }^{8}$ We chose to measure the effects of bevacizumab on the clotting tendency of blood using the contact activation pathway and extrinsic coagulation pathway, due to the ease and accessibility of the aPTT and PT tests. The present study found that ophthalmic doses of bevacizumab shortened PT relative to control at $2 \mathrm{~h}$. Decreased PT indicates increased in vitro coagulation, and therefore this may be a possible mechanism for ATEs at ophthalmic doses of bevacizumab.

VEGF is a signal protein produced by cells that stimulate the growth of new blood vessels. VEGF induces vascular hyperpermeability, which allows plasma proteins, such as coagulation factors, to leak into the extracellular matrix. Bevacizumab's effects on vasoconstrictive and vasodilatory factors may explain our findings that demonstrate a lower mean PT compared with controls. Bevacizumab influences factors such as endothelin-1 and nitric oxide, which are influenced by VEGF. ${ }^{9}$ When bevacizumab affects vasoconstrictive and vasodilatory factors, it may increase coagulation. $^{9}$

A potential limitation of the present study is the stability of the PNP, which can be affected as time progresses in the processor, especially when incubated. This may explain the observed findings of decreased $2 \mathrm{~h}$ PT at 0.25, 1.25, 2.0, 2.5, and $4.0 \mathrm{mg}$, but not at 0.5 or $1.0 \mathrm{mg}$ doses. However, mixing each sample immediately before analysis and running several controls helped to minimize error. Our study compared PT and aPTT between control and experimental samples within each time point of interest $(30 \mathrm{~min}, 1 \mathrm{~h}$, and $2 \mathrm{~h}$ ), to control for degradation over time. All the platings and

Table 1. Trial Times of Activated Partial Thromboplastin Time and Prothrombin Time at Varying Doses of Bevacizumab

\begin{tabular}{|c|c|c|c|c|c|c|}
\hline & \multicolumn{3}{|c|}{ aPTT in seconds, mean \pm standard deviation } & \multicolumn{3}{|c|}{ PT in seconds, mean \pm standard deviation } \\
\hline & $0.5 h$ & $1 h$ & $2 h$ & $0.5 \mathrm{~h}$ & $1 h$ & $2 h$ \\
\hline Control, $40 \%$ normal saline & $40.1 \pm 1.0$ & $40.0 \pm 1.0$ & $40.5 \pm 0.9$ & $16.5 \pm 0.9$ & $15.5 \pm 0.0$ & $15.4 \pm 0.9$ \\
\hline \multicolumn{7}{|l|}{ Bevacizumab } \\
\hline $0.25 \mathrm{mg}$ & $38.4 \pm 1.2$ & $37.4 \pm 0.3$ & $40.0 \pm 3.5$ & $15.7 \pm 0.7$ & $14.9 \pm 0.1$ & $14.4 \pm 0.3^{\mathrm{a}}$ \\
\hline $0.5 \mathrm{mg}$ & $39.6 \pm 3.2$ & $37.6 \pm 0.6$ & $39.5 \pm 2.8$ & $15.7 \pm 0.4$ & $15.3 \pm 0.2$ & $14.8 \pm 0.1$ \\
\hline $1.0 \mathrm{mg}$ & $43.9 \pm 2.3$ & $41.9 \pm 4.1$ & $43.2 \pm 2.3$ & $16.5 \pm 0.1$ & $16.2 \pm 0.1$ & $15.8 \pm 0.4$ \\
\hline $1.25 \mathrm{mg}$ & $40.1 \pm 2.7$ & $43.1 \pm 2.6$ & $42.1 \pm 2.5$ & $15.8 \pm 0.5$ & $15.1 \pm 0.6$ & $14.3 \pm 0.5^{\mathrm{a}}$ \\
\hline $2.0 \mathrm{mg}$ & $39.0 \pm 0.8$ & $39.6 \pm 2.1$ & $40.4 \pm 3.7$ & - & - & - \\
\hline $2.5 \mathrm{mg}$ & $40.1 \pm 1.5$ & $40.6 \pm 1.7$ & $40.5 \pm 1.6$ & $16.1 \pm 0.6$ & $15.9 \pm 0.3$ & $14.5 \pm 0.6^{\mathrm{a}}$ \\
\hline $4 \mathrm{mg}$ & $40.6 \pm 1.3$ & $39.1 \pm 0.4$ & $39.0 \pm 0.5$ & $16.8 \pm 1.2$ & $14.6 \pm 0.3$ & $14.0 \pm 0.1^{\mathrm{a}}$ \\
\hline
\end{tabular}

aStatistically significant difference compared with control $(P \leq 0.05)$.

-, no data; aPTT, activated partial thromboplastin time; PT, prothrombin time. 
readings were performed within $1 \mathrm{~h}$, which is well within the experimentally derived window of $2 \mathrm{~h}$. This procedure ensures that results accurately reflect the drug's effects on the PNP and not the breakdown of PNP from temperature and time.

In summary, the present study suggests that bevacizumab significantly affects the human coagulation cascade by increasing coagulation at a common ophthalmic dose of $1.25 \mathrm{mg}$, and at both lower and higher doses. These findings may provide a mechanism for thrombosis and underscore the importance of further research on the effect of ophthalmic bevacizumab on the coagulation cascade.

\section{Acknowledgments}

We gratefully acknowledge Leslie Pierson, Core Laboratory Supervisor, and Michael Kline, M.D., former Chief of Laboratory Services, Providence Veterans Affairs Medical Center, for laboratory analysis of the samples. This material is the result of work supported with resources and the use of facilities at the Providence Veterans Affairs Medical Center. This study was unfunded.

\section{Disclaimer}

The views expressed in this article are those of the authors and do not necessarily reflect the position or policy of the Department of Veterans Affairs or the U.S. government.

\section{Author Disclosure Statement}

No competing financial interests exist.

\section{References}

1. Gunther, J.B., and Altaweel, M.M. Bevacizumab (Avastin) for the treatment of ocular disease. Surv. Ophthalmol. 54:372-398, 2009.
2. Reidy, D.L., Chung, K.Y., Timoney, J.P., et al. Bevacizumab $5 \mathrm{mg} / \mathrm{kg}$ can be infused safely over 10 minutes. J. Clin. Oncol. 25:2691-2695, 2007.

3. Shord, S.S., Bressler, L.R., Tierney, L.A., Cuellar, S., and George, A. Understanding and managing the possible adverse effects associated with bevacizumab. Am. J. Health Syst. Pharm. 66:999-1013, 2009.

4. "Warnings and Precautions." Avastin (Bevacizumab). South San Francisco, CA: Genentech, Inc.; 2010.

5. Curtis, L.H., Hammil, B.G., Schulman, K.A., and Cousins, S.W. Risks of mortality, myocardial infarction, bleeding, and stroke associated with therapies for age-related macular degeneration. Arch. Ophthalmol. 128:1273-1279, 2010.

6. CATT Research Group, Martin, D.F., Maguire, M.G., et al. Ranibizumab and bevacizumab for neovascular age-related macular degeneration. N. Engl. J. Med. 364:1897-1908, 2011.

7. Abouammoh, M., and Sharma, S. Ranibizumab versus bevacizumab for the treatment of neovascular age-related macular degeneration. Curr. Opin. Ophthalmol. 22:152-158, 2011.

8. Lippi, G., Favaloro, E.J., Franchini, M., and Guidi, G.C. Milestones and perspectives in coagulation and hemostasis. Semin. Thromb. Hemost. 35:9-22, 2009.

9. Pattwell, D.M., Stappler, T., Sheridan, C., et al. Fibrous membranes in diabetic retinopathy and bevacizumab. Retina. 30:1012-1016, 2010.

Received: August 10, 2011

Accepted: December 27, 2011

Address correspondence to: Dr. Kerry L. LaPlante Infectious Diseases Research Laboratory, Research Service Veterans Affairs Medical Center (151) Research Building \#35 830 Chalkstone Ave. Providence, RI 02908

E-mail: kerrylaplante@uri.edu 
Copyright of Journal of Ocular Pharmacology \& Therapeutics is the property of Mary Ann Liebert, Inc. and its content may not be copied or emailed to multiple sites or posted to a listserv without the copyright holder's express written permission. However, users may print, download, or email articles for individual use. 